\title{
Compressibility and consolidation of water treatment residues
}

B. C. O'Kelly MEngSc, PhD, CEng, CEnv, MICE, FIEl, PGeo, MIGI, FGS and M. E. Quille BA, BAI, MIEl

The index, compression and consolidation properties are presented for alum water treatment residues (WTRs) derived from three different catchments and dewatered using different methods. Oedometer, consolidometer and triaxial consolidation tests were carried out on specimens of different size and consistency over a wide range of applied stresses (3-800 $\mathrm{kPa}$ ) and under different drainage conditions. The solids fraction mainly comprised organic matter and micro-organisms (loss-in-dry-mass on ignition of between 40 and $60 \%$ ) and hence the residues had a low specific gravity of solids of $1.83-1.99$ and a low dry density of $0.14-0.26 \mathrm{t} / \mathrm{m}^{3}$ measured over the mass water content range of $300-700 \%$. The wet residue was highly compressible (primary compression index of $2 \cdot 1-3 \cdot 1$ ) and the lagooned or landfilled material will settle significantly, but over a long period of time, due to its low consolidation and high creep rates (coefficient of consolidation of $0.1-0.8 \mathrm{~m}^{2} /$ year and secondary compression index of $0.005-0.010)$. The WTRs had a very low hydraulic conductivity (coefficient of permeability of $10^{-9}-10^{-11} \mathrm{~m} / \mathrm{s}$ ) due to the microstructure of the constituent flocs, the high organic content and alum's exceptionally high affinity for water. Although the non-chemically coagulated residue was found to be slightly more compressible, the geoengineering properties were generally independent of seasonal variations in the source waters and the catchment geology.

\section{INTRODUCTION}

Water treatment residues (WTRs) are the sludge materials derived from the filter backwash, water softening, chemical coagulation, flocculation and settling processes used in the treatment of potable water. ${ }^{1}$ WTRs comprise sand and silt particles, organic matter and micro-organisms, as well as chemicals (coagulants, polyelectrolytes and conditioning agents) that are added to the source water during the treatment processes. Chemical coagulants, principally aluminium sulphate $\left(\mathrm{Al}_{2}\left(\mathrm{SO}_{4}\right)_{3}\right)$ and ferric chloride $\left(\mathrm{FeCl}_{3}\right)$, aggregate the suspended particles present in the source water by entrapment within a gelatinous hydroxide matrix and these larger flocs are more readily separated out by settling processes. The residues are characterised as alum or iron WTR depending on the coagulant type used. Polyelectrolytes are coagulant aids comprising synthetic, long-chained organic molecules (that may be cationic, anionic or non-ionic) and which act as binding agents to increase the inherent shear strength of the newly formed flocs. Conditioning agents such as activated silica, sodium silicate, bentonite, calcium/sodium hydroxide, sulphuric acid and soda ash may also be added depending on the nature of the source water in order to improve the polyelectrolyte performance.

Residue disposal is an increasing problem worldwide because municipal water treatment plants are producing greater volumes of WTRs due to the increasing global demand for potable water. For example, $12000 t$ of dewatered WTRs were produced in Ireland in 2000; this figure is expected to increase to $20000 \mathrm{t}$ by $2020 .^{2}$ At present, most WTRs are disposed of by landfilling the material at monofills, municipal landfills or often by indefinite storage in shallow or deep lagoons. However, more stringent regulations (including, for example, the waste management and water treatment directives ${ }^{3,4}$ ) have restricted disposal options in order to minimise the environmental impacts. Along with environmental concerns, the disposal of large WTR volumes at landfills can lead to geotechnical problems such as slope instability and differential settlement.

The residues are dewatered at water treatment plants by mechanical means and/or by allowing the residues to air dry naturally in shallow drying beds or lagoons. Dewatering reduces the overall volume, thereby reducing transportation and landfill-disposal costs, as well as increasing the shear strength. Table $1^{5}$ shows the performance in terms of representative final solids content (SC, defined as the mass of solids as a percentage of the wet residue mass) achieved by different thickening and mechanical dewatering processes at water treatment plants. Different dewatering processes produce WTRs of different consistencies, with SC ranging between 1 and 60\% (Table 1).

WTRs are soil-like materials and, as such, their behaviour in a lagoon, monofill or dedicated deposition area at a municipal landfill can be assessed using soil mechanics theory. Previous research $^{6-12}$ on the engineering properties of alum WTRs indicated that these materials have very high liquid and plastic limit values, similar to those of high-plasticity organic clays. The low specific gravity of solids ranges between 1.8 and 2.3 and the wet residue (i.e. direct from the treatment plant) has a low bulk density of $1 \cdot 0-1 \cdot 2 \mathrm{t} / \mathrm{m}^{3}$. The WTRs are highly compressible. For example, very high primary compression index $\left(C_{\mathrm{c}}\right.$, defined as the gradient of the void ratio versus logarithm of applied stress curve under one-dimensional loading conditions) values of 5.3-6.7 


\begin{tabular}{|lcc|}
\hline \multirow{2}{*}{ Process } & \multicolumn{2}{c|}{ Performance } \\
\cline { 2 - 3 } & $\begin{array}{c}\text { Solids content: } \\
\%\end{array}$ & $\begin{array}{c}\text { Water content: } \\
\%\end{array}$ \\
\hline Gravity thickener & $1-7$ & $9900-1330$ \\
Lamella plate & $3-10$ & $3235-900$ \\
Centrifuge & $10-18$ & $900-455$ \\
Belt press & $15-20$ & $570-400$ \\
Lagooning & $15-40$ & $570-150$ \\
Recessed-plate filter press & $20-30$ & $400-235$ \\
Drying bed & $30-60$ & $230-70$ \\
& & \\
\hline Table I. Final solids and water contents of WTR achieved by \\
thickening and dewatering processes
\end{tabular}

were reported for an alum WTR derived from a medium-high in colour and low-medium turbidity source water that had been dewatered using a centrifuge and sand-drying method. ${ }^{12}$ Alum WTR has a very low hydraulic conductivity due to the electrovalent character of the aluminium ions $\left(\mathrm{Al}^{3+}\right)$ that trap a greater number of water molecules within the aluminium hydroxide matrix compared with other coagulants, including ferric chloride. The coefficient of permeability of such WTRs was found to reduce from typically $10^{-8}$ to $10^{-10} \mathrm{~m} / \mathrm{s}$ with increasing applied stress. ${ }^{13}$ Knowledge of the consolidation and hydraulic conductivity properties is important in understanding and predicting the longer-term behaviour of WTRs disposed of at lagoons or monofill sites.

WTRs are similar in some respects to municipal wastewater sludges, and extensive research on the compressibility and consolidation properties of wastewater sludges has been reported by 0'Kelly. ${ }^{14-17}$ However, municipal wastewater sludges are bioactive and usually have moderate to strong levels of biodegradation, whereas WTRs are relatively inert.

The aims of this paper are to present the range of compression and consolidation properties of alum WTRs derived from three different catchments, and to study the effects of bedrock geology and chemicals added during treatment processes at municipal works. The use of experimental data in selecting an appropriate mechanical dewatering system is described, along with a method for predicting the settlement response of WTR lagoons and monofills.

\section{TEST MATERIALS}

Alum WTRs were sourced from three of the larger municipal water treatment plants in Ireland (Ballymore Eustace and Leixlip in County Kildare and Clareville in County Limerick). Together, these plants account for almost 30\% of the potable water produced in Ireland per annum. ${ }^{2}$ The raw water from the plants is sourced from three different catchments, thereby providing a good overall representation of the range of alum WTRs produced in the country. The alum WTRs had been coagulated using Chemifloc 4140 and conditioned using Magnafloc LT25 polyelectrolyte, both manufactured by Allied Colloids and Ciba Zietag. Table 2 lists the chemical dosages added at the treatment plants prior to dewatering the residues. The dosages were at the higher end of the ranges normally used as the source waters were medium-high in turbidity.

\begin{tabular}{lcccc} 
Additive & WTR I & WTR 2a & WTR 2b & WTR 3 \\
\hline $\begin{array}{l}\text { Alum: mg/l } \\
\text { Polyelectrolyte: mg/l }\end{array}$ & $40-65$ & $60-100$ & 0 & $40-60$ \\
$\begin{array}{l}\text { Dry sulphuric acid: kg/day } \\
0\end{array}$ & 0 & 0.5 & 0 & 0 \\
& & & & $0 \cdot 2-1 \cdot 0$ \\
$\begin{array}{l}\text { Table 2. Dosages of chemicals added during treatment } \\
\text { processes }\end{array}$
\end{tabular}

\section{I. Sample WTR I}

The residue from Ballymore Eustace (WTR 1) was a brownishgreen material derived from the treatment of a medium-colour medium-turbidity raw water that had been sourced from the Dublin and Wicklow mountains (upland catchment of peat over granite bedrock), and stored in Poulaphouca reservoir, County Wicklow. The slurry residue was dewatered using a recessed-plate filter press (applied stress of $1500 \mathrm{kPa}$ ), with about $1200 \mathrm{t}$ of wet residue ( $S C \approx 23 \%$ ) produced at the plant in 2007 . Samples of the residue cake were obtained from skip containers at the end of the dewatering process at the treatment plant in November 2005.

\subsection{Sample WTR 2a}

The residue from Clareville (WTR 2a) was a brownish-green material derived from the treatment of high-colour highturbidity raw water that had been sourced from the River Shannon (lowland catchment of peat over limestone bedrock). Sulphuric acid had been added to adjust the $\mathrm{pH}$ of the source water in order to improve the coagulant performance. The slurry residue was dewatered using a mechanical belt-press (applied stress of $800-1000 \mathrm{kPa}$ ) and allowed to naturally air dry in lagoons, with about $900 \mathrm{t}$ of the wet residue ( $\mathrm{SC} \approx 15 \%$ ) produced at the plant in 2006. Residue samples were obtained from the drying beds at the municipal plants in October 2006.

\subsection{Sample WTR $2 b$}

Material WTR $2 \mathrm{~b}$ was the slurry residue sourced from the Clareville treatment plant directly after the initial screening process, but without the addition of any chemicals. A column of the thickened suspension was allowed to naturally settle out under gravity and dried by evaporation at $21^{\circ} \mathrm{C}$ in the geotechnical laboratory. Material WTR 2b was obtained in February 2008 with the aim of studying the effect of chemical additives on compression and consolidation properties.

\subsection{Sample WTR 3}

The residue from Leixlip (WTR 3) was a dark brown material derived from the treatment of a medium-colour mediumturbidity raw water that had been sourced from the River Liffey (upland catchment of limestone bedrock). The residue was dewatered using a recessed-plate filter press (applied stress of $1500 \mathrm{kPa}$ ), with about $1100 \mathrm{t}$ of wet residue (SC $\approx 25 \%$ ) produced at the plant in 2007. Samples of the residue cake were obtained from skip containers at the end of the dewatering process at the treatment plant in November 2006.

\section{INDEX AND PHYSIOCHEMICAL PROPERTIES}

Table 3 lists the index and physiochemical properties of the WTRs determined using standard geotechnical-laboratory tests $^{18,19}$ on residues obtained directly from the treatment plants. In this work, the amount of pore water in the material was quantified in terms of the mass water content $(w)$, defined 


\begin{tabular}{|lcccc}
\hline Parameter & WTR & WTR & WTR & WTR \\
& $\mathrm{I}$ & $2 \mathrm{a}$ & $2 \mathrm{~b}$ & 3 \\
\hline Water content: \% & 340 & 570 & 700 & 300 \\
Solids content: \% & 23.0 & 15.0 & 12.5 & 25.0 \\
Liquid limit: \% & 490 & 550 & 550 & 430 \\
Plastic limit: \% & 240 & 260 & 280 & 325 \\
Plasticity index & 250 & 290 & 270 & 105 \\
Bulk density: $\mathrm{t} / \mathrm{m}^{3}$ & 1.08 & 1.06 & 1.04 & 1.10 \\
Dry density: $\mathrm{t} / \mathrm{m}^{3}$ & 0.25 & 0.18 & 0.14 & 0.26 \\
Specific gravity of solids & 1.86 & 1.99 & 1.83 & 1.90 \\
LOI: \% & 57 & 45 & 41 & 46 \\
Linear shrinkage: \% & 47 & 45 & 38 & 48 \\
Free swell: \% & 35 & 10 & 10 & 40 \\
Void ratio & 6.3 & 11.3 & 14.6 & 5.7 \\
Adhesion limit: \% & 240 & 365 & 355 & 345 \\
pH & 8.6 & $7 \cdot 1$ & 7.9 & 7.2 \\
\hline
\end{tabular}

Notes. Bulk and dry density, total wet mass and dry solids mass per unit volume; WTR I derived from upland catchment of peat over granite bedrock; WTRs $2 \mathrm{a}$ and $2 \mathrm{~b}$ from lowland catchment of peat over limestone bedrock; WTR 3 from upland catchment of limestone bedrock

Table 3. Properties of residues obtained directly from treatment plants

as the ratio of the mass of pore water to the mass of dry solids, expressed as a percentage. The water content value was determined using the oven-drying method in which the mass of the dry solids corresponds to the equilibrium mass achieved after oven drying the test specimen at $105 \pm 5^{\circ} \mathrm{C}$, usually for a period of $24 \mathrm{~h}$. A black, brittle, crystalline precipitate was produced on oven drying the residue specimens. The mass water content $w$ and the SC, generally used in geotechnical and water-treatment literature respectively, are related by

\begin{tabular}{|l|l|}
\hline $\mathrm{S}$ & $\mathrm{SC}=\frac{100}{1+(w / 100)}(\%)$ \\
\hline
\end{tabular}

The liquid and plastic limits were determined using Atterberg tests and the plasticity index values were calculated as the difference between the liquid and plastic limit values. WTRs have very high liquid limit (430-550\%) and plasticity index (105-290) values and are classified as high-plasticity organic clay. A similar range of Atterberg limit values has been reported for WTRs by Wang et al. ${ }^{12} \mathrm{X}$-ray diffraction analysis of wet and dry WTR specimens indicated that the crystalline fraction comprised quartz $\left(\mathrm{SiO}_{2}\right)$ and manganoan calcite $\left.\left[(\mathrm{Ca}, \mathrm{Mg}) \mathrm{CO}_{3}\right)\right]$, which are both common bedrock minerals and present as fines in the source waters. The chemical additives did not feature in the X-ray diffraction analysis since alum is predominately in an amorphous form (disordered and without any definable crystalline structure) and the polyelectrolytes are organic molecules.

The different dewatering methods produced residues of different consistencies. WTRs 2a and 2b were of a slurry consistency (i.e. water content greater than the liquid limit condition, where the liquid limit equates to an undrained shear strength $\boldsymbol{s}_{\mathrm{u}}<1.7 \mathrm{kPa}$ ). WTRs 1 and 3 were soft to firm in consistency due to the higher levels of dewatering that had been achieved under the greater stresses applied by the recessed-plate filter press. Nevertheless, the initial void ratio (i.e. volume of void space to the volume of solid particles) was still very high, ranging between $5 \cdot 7$ and $14 \cdot 6$ (porosity $=6 \cdot 1-18 \cdot 6 \%$ ).
The loss-in-dry-mass on ignition (LOI) was determined by igniting dry, powered specimens in a muffle furnace at $440^{\circ} \mathrm{C}$. The LOI value is a reflection of the organic content because the crystalline fraction remains stable at the ignition temperature of $440^{\circ} \mathrm{C}$. Calcination to form lime occurs at a much higher temperature of about $850^{\circ} \mathrm{C}$. Furthermore, the concentration of chemical additives, which are unstable at a temperature above about $150^{\circ} \mathrm{C}$, was very low. The high LOI values (41-57\%) indicated that the constituent solids mainly comprised organic matter and micro-organisms. The ash residue of black sand-like grains from the LOI tests was non-plastic, which indicated that the material's high plasticity was due to its high organic content.

The bulk density and dry density were calculated as the total wet mass and dry mass per unit volume, respectively. The dewatered residues from the treatment plants had low bulk and dry density values of $1 \cdot 04-1 \cdot 10$ and $0 \cdot 14-0 \cdot 26 \mathrm{t} / \mathrm{m}^{3}$, respectively. The specific gravity of solids $G_{\mathrm{s}}$ (i.e. the ratio of the density of solids to density of water) was measured using the small pyknometer method, ${ }^{18}$ using kerosene in place of distilled water as the fluid in the pyknometer bottles. The $G_{\mathrm{s}}$ values of 1.83 to 1.99 for the WTRs were found to be low compared with the those of mineral soils (typically $2 \cdot 5-2 \cdot 7$ ); however, the measured $G_{\mathrm{s}}$ values were consistent with the low dry density values and similar to those reported for other alum WTRs by Wang et al. ${ }^{12}$

Linear shrinkage was calculated as the percentage reduction in the length of a bar of wet residue, initially $133 \mathrm{~mm}$ long, that had been oven dried from the liquid limit condition. The linear shrinkage values of 38 to $48 \%$ were very high, indicating that substantial reductions in volume would occur by natural air drying of the wet lagooned residue. The free swell values (i.e. the maximum volumetric expansion on full resaturation of the powered, oven-dried material ${ }^{20}$ ) were also high, although consistent with the high plasticity index values. The adhesion limit (determined as the lowest water content at which the solids adhered to a clean dry spatula that had been lightly drawn over a moist residue pat) values were very high, and in excess of 240\% water content. Handling, transportation and landfill operations may prove more difficult at water content values greater than the adhesion limit, due, in part, to the tendency of the residue to adhere to machine plant.

The $\mathrm{pH}$ values, measured using an electrometric method, ${ }^{19}$ were slightly alkaline due to the addition of chemicals and conditioning of the source waters during the treatment processes. Titshall and Hughes ${ }^{21}$ have reported similar $\mathrm{pH}$ values for other alum WTRs.

Allowing for the natural variability of the source waters and the fact that sampling of the test materials occurred at different times of the year, the WTRs generally have similar index and physiochemical properties, irrespective of chemical additives or catchment geology. There was a marginal difference in $\mathrm{pH}$ of the chemically and non-chemically coagulated residues (WTRs $2 \mathrm{a}$ and $2 \mathrm{~b}$, respectively), which was to be expected since some sulphuric acid had been added to the source water in the case of WTR 2a in order to improve the polyelectrolyte performance. It is postulated that the lower plasticity index value measured for WTR 3 is partly related to the catchment geology - that is, limestone bedrock compared with peat deposits over bedrock for WTRs $1,2 \mathrm{a}$ and $2 \mathrm{~b}$. 


\section{COMPRESSION AND CONSOLIDATION PROPERTIES}

\section{I. Experimental method}

4.1.1. Range of test conditions. The compression and consolidation properties of the residues were determined by testing saturated specimens of different size and consistency, under different drainage and loading conditions, using oedometer, consolidometer and triaxial apparatus (Table 4). The wide range of applied stresses (3-800 $\mathrm{kPa}$ ) covered the diverse stress levels experienced in mechanically dewatering, storage and landfilling - that is, low stress levels in a lagoon, low to medium stress levels in landfill deposits and medium to very high stress levels applied by mechanical dewatering systems at treatment plants. The compression tests were carried out on saturated, freshly remoulded material. It has been experimentally demonstrated that curing periods of up to two months do not alter the hydraulic conductivity properties of alum WTRs $;^{13}$ the compression and consolidation properties measured for freshly remoulded material in this study are therefore also likely to be representative of its long-term behaviour in a lagoon or monofill.

\subsubsection{Oedometer. Saturated specimen pairs of uniform} consistency were prepared by thoroughly mixing the wet residues (obtained directly from treatment plants) with distilled water and allowing the slurry mixtures to equilibrate in sealed containers for a period of at least $48 \mathrm{~h}$. The slurry was then pressed into the oedometer cell (76.2 $\mathrm{mm}$ diameter) using a spatula, taking care to avoid the entrapment of air voids. Each load stage was applied for a period of two days in order to record sufficient data covering both consolidation and creep settlement processes. The applied vertical stress was doubled in moving from one load stage to the next over the stress range 3-800 $\mathrm{kPa}$. The specimen had saturated porous stones in full contact with both its ends (i.e. two-way drainage conditions). A displacement transducer in contact with the specimen loading cap continuously measured the deformation response.

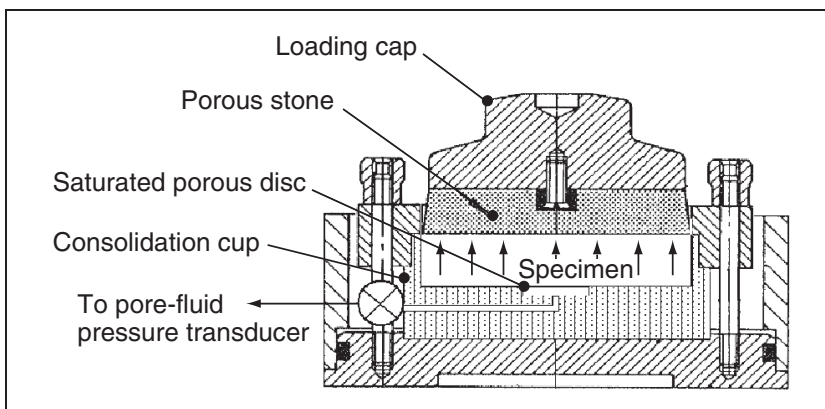

Figure I. Oedometer cell incorporating pore-fluid pressure measurement (one-way drainage)

Specimens were also tested in the oedometer apparatus under one-way drainage conditions. Drainage was only allowed to occur from the top of the specimen in a specially designed consolidation cup, with continuous measurement of the excess pore-fluid pressure response by a pressure transducer via a saturated porous disc located in its base (Figure 1). With practically the same effective drainage lengths and similar initial water contents and void ratios, similar experimental data were expected for the specimen pairs, in accordance with Terzaghi's theory of one-dimensional consolidation. ${ }^{22}$

4.1.3. Consolidometer. A saturated slurry was prepared in the same manner as the oedometer specimens, placed in a $152 \mathrm{~mm}$ diameter consolidometer press developed by 0 'Kelly ${ }^{23}$ and periodically roded to remove any trapped air. The specimen was then compressed one-dimensionally under applied stresses of 10, 16 and $30 \mathrm{kPa}$, with two-way drainage to atmosphere via saturated porous stones in full contact with both ends. Each load stage was applied for a longer period of seven days because of the greater effective drainage length. Periodic measurements of the deformation response were taken using a long-stroke dial gauge in contact with the specimen loading platen.

\begin{tabular}{|c|c|c|c|c|c|c|c|c|c|}
\hline \multirow[t]{2}{*}{ Test } & \multirow{2}{*}{$\begin{array}{l}\text { Specimen } \\
\text { diameter } \times \\
\text { height: } \mathrm{mm}\end{array}$} & \multirow[t]{2}{*}{ Consistency } & \multicolumn{2}{|c|}{$\begin{array}{c}\text { Water } \\
\text { content: \% }\end{array}$} & \multirow[t]{2}{*}{$\begin{array}{l}\text { Applied stress: } \\
\mathrm{kPa}^{*}\end{array}$} & \multicolumn{2}{|c|}{$\begin{array}{l}\text { Void } \\
\text { ratio }\end{array}$} & \multirow{2}{*}{$\begin{array}{l}\text { Duration } \\
\text { load stage: } \\
\text { days }\end{array}$} & \multirow[t]{2}{*}{$\begin{array}{l}\text { Drainage } \\
\text { conditions }\end{array}$} \\
\hline & & & Initial & Final & & Initial & Final & & \\
\hline \multicolumn{10}{|l|}{ Oedometer } \\
\hline WTR I & $76.2 \times 29.0$ & Slurry & 780 & 280 & $\sigma_{\mathrm{v}}=3-800(\mathrm{MI})$ & 14.5 & $6 \cdot 2$ & 2 & Two-way \\
\hline WTR I & $76.2 \times 15.8$ & Slurry & 780 & 280 & $\sigma_{\mathrm{v}}=3-800(\mathrm{MI})$ & 14.5 & $6 \cdot 2$ & 2 & One-way \\
\hline WTR 2a & $76.2 \times 29.0$ & Slurry & 700 & 190 & $\sigma_{\mathrm{v}}=3-800(\mathrm{MI})$ & $|4 \cdot|$ & $3 \cdot 3$ & 2 & Two-way \\
\hline WTR 2a & $76.2 \times 15.8$ & Slurry & 710 & 205 & $\sigma_{\mathrm{v}}=3-800(\mathrm{MI})$ & $|4 \cdot|$ & $3 \cdot 3$ & 2 & One-way \\
\hline WTR 3 & $76.2 \times 29.0$ & Slurry & 690 & 310 & $\sigma_{\mathrm{v}}=3-800(\mathrm{MI})$ & 11.9 & $5 \cdot 4$ & 2 & Two-way \\
\hline WTR 3 & $76.2 \times 15.8$ & Slurry & 700 & 315 & $\sigma_{\mathrm{v}}=3-800(\mathrm{MI})$ & $12 \cdot 1$ & $5 \cdot 4$ & 2 & One-way \\
\hline \multicolumn{10}{|c|}{ Consolidometer } \\
\hline WTR I & $152.0 \times 139.0$ & Slurry & 625 & 475 & $\sigma_{\mathrm{v}}=10-30(\mathrm{MI})$ & $|4 \cdot|$ & 8.8 & 7 & Two-way \\
\hline WTR 2a & $152.0 \times 139.0$ & Slurry & 580 & 420 & $\sigma_{\mathrm{v}}=10-30(\mathrm{MI})$ & 10.9 & $8 \cdot 4$ & 7 & Two-way \\
\hline WTR 2b & $152.0 \times 167.0$ & Slurry & 760 & 435 & $\sigma_{\mathrm{v}}=10-30(\mathrm{MI})$ & $15 \cdot 4$ & $8 \cdot 1$ & 7 & Two-way \\
\hline WTR 3 & $152.0 \times 93.0$ & Slurry & 600 & 410 & $\sigma_{\mathrm{v}}=10-30(\mathrm{MI})$ & $\mid I \cdot 1$ & $7 \cdot 8$ & 7 & Two-way \\
\hline \multicolumn{10}{|c|}{ Isotropic triaxial } \\
\hline WTR I & $38.0 \times 76.0$ & Very soft & 475 & 340 & $\boldsymbol{\sigma}_{\mathrm{c}}^{\prime}=30-150(\mathrm{SI})$ & 8.8 & $7 \cdot 3$ & I & All around \\
\hline WTR 2a & $38.0 \times 76.0$ & Very soft & 420 & 350 & $\sigma_{c}^{\prime}=30-150(\mathrm{SI})$ & $8 \cdot 4$ & $7 \cdot 9$ & I & All around \\
\hline WTR $2 b$ & $38.0 \times 76.0$ & Very soft & 435 & 340 & $\sigma_{\mathrm{c}}^{\prime}=30-150(\mathrm{SI})$ & $8 \cdot 1$ & $7 \cdot 2$ & I & All around \\
\hline WTR 3 & $38.0 \times 76.0$ & Very soft & 410 & 300 & $\sigma_{\mathrm{c}}^{\prime}=30-150(\mathrm{SI})$ & $7 \cdot 8$ & $6 \cdot 7$ & I & All around \\
\hline
\end{tabular}

* MI, multi increment; SI, single increment; $\boldsymbol{\sigma}_{\mathrm{v}}$, applied vertical stress; $\boldsymbol{\sigma}_{\mathrm{c}}^{\prime}$, effective cell-confining pressure 
4.1.4. Triaxial consolidation. Compression and consolidation properties were also measured using a triaxial consolidation test, with continuous measurement of the pore-fluid pressure response. ${ }^{24}$ Sets of four triaxial specimens, $38.0 \mathrm{~mm}$ diameter and $76.0 \mathrm{~mm}$ high, were prepared from each of the residue cakes produced at the end of the consolidometer tests. A back pressure $\left(\mathbf{u}_{\mathrm{b}}\right)$ of $200 \mathrm{kPa}$ was applied to the triaxial specimens to ensure that they remained in a fully saturated condition, which was confirmed by measuring a Skempton pore pressure coefficient $B>0.98$. Isotropic cell-confining pressures of 230, 260, 320 and $350 \mathrm{kPa}$ were applied to each specimen set. The specimens were allowed to drain radially and from both ends for a period of $24 \mathrm{~h}$, with continuous measurement of the fluid volume draining from the specimens. Effective cell-confining pressure $\left(\boldsymbol{\sigma}_{\mathrm{c}}^{\prime}\right.$, defined as the applied cell-confining pressure minus the excess pore-fluid pressure) values of 30,60,120 and $150 \mathrm{kPa}$ were achieved by the end of the $24 \mathrm{~h}$ consolidation period.

\section{EXPERIMENTAL RESULTS AND ANALYSIS}

\section{I. Oedometer}

Figure 2 shows the oedometer data plotted in the conventional form of cumulative strain against logarithm of elapsed time for WTRs 1, 2a and 3. As expected, the slurry specimens were highly compressible, deforming at a slow but steady rate. By the

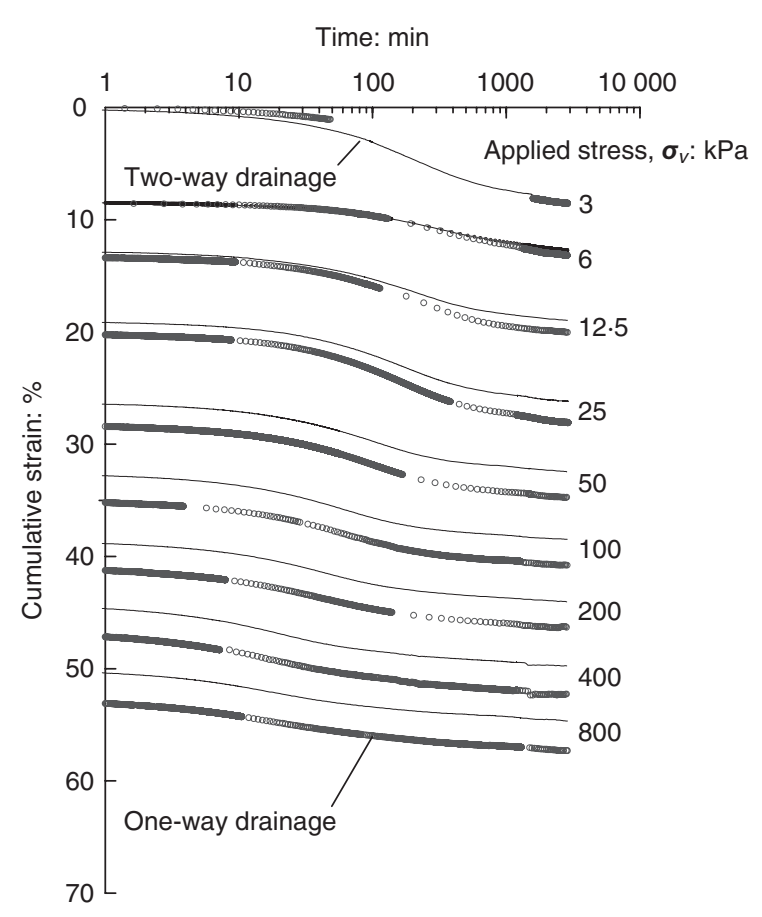

(a)

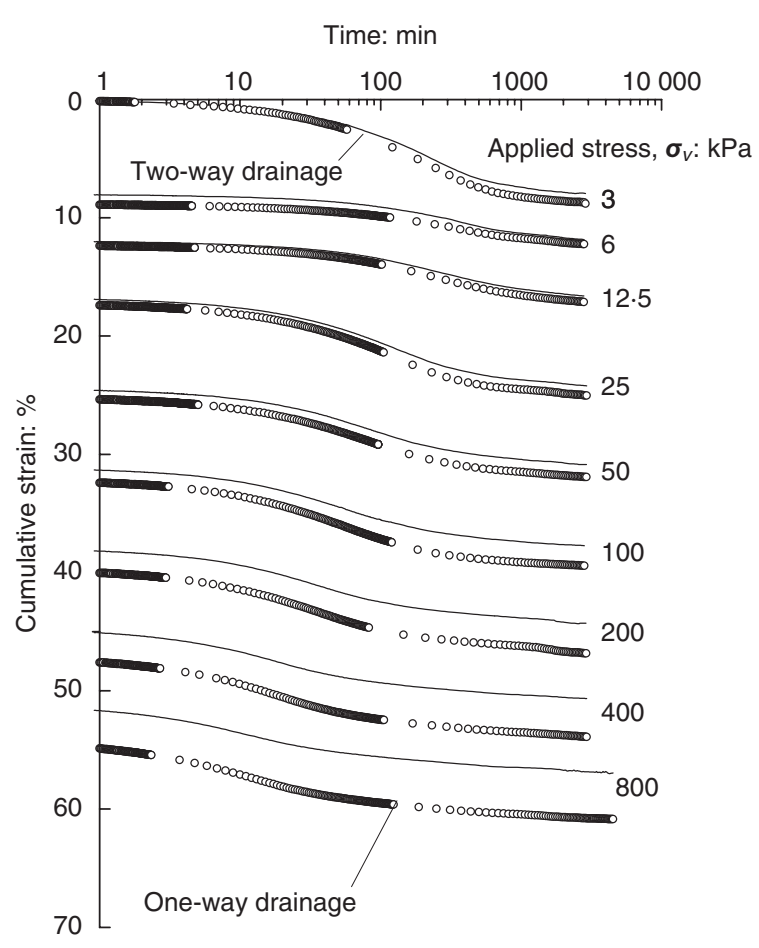

(b)

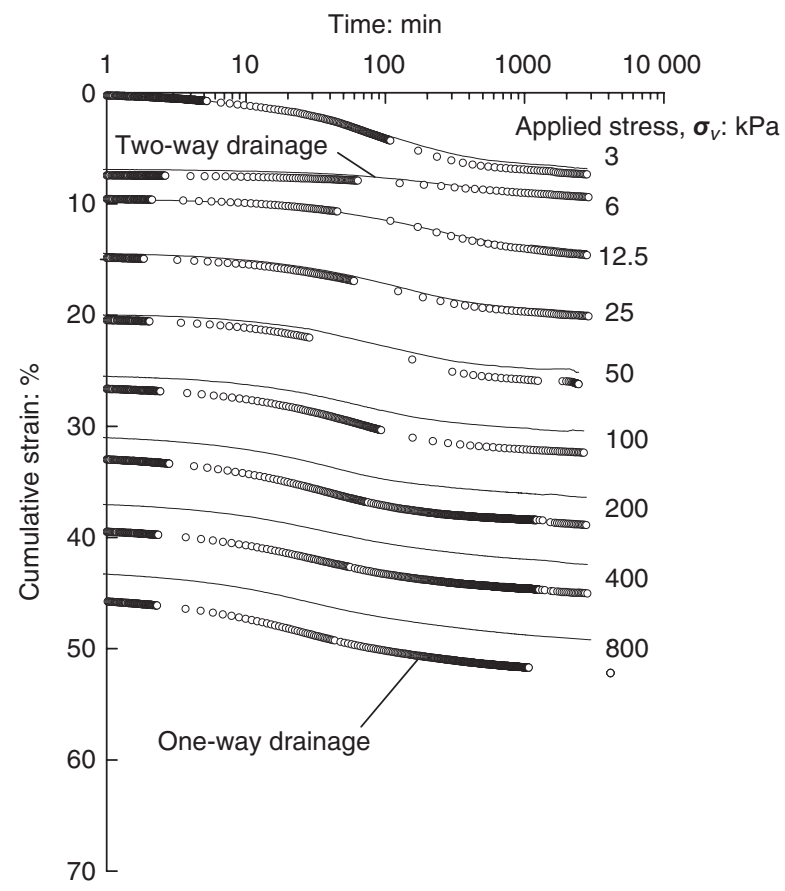

(c) 
end of the final load stage $(800 \mathrm{kPa})$, they had experienced very large strains of $49-57 \%$ and $52-61 \%$ under one- and two-way drainage conditions, respectively.

The characteristic S-shaped curves were evident and the negligible strain measured at the start of each load step indicated that the specimens were in a fully saturated state. The initial compression ratio (i.e. instantaneous strain on applying stress increment, expressed as a percentage of the total strain for that particular load stage) generally ranged between only 0.02 and 0.08 . Primary consolidation due to dissipation of excess pore-fluid pressure was dominant during the early load stages, with the primary compression ratio (i.e. the primary consolidation component expressed as a percentage of the total strain for that particular load stage) initially $0 \cdot 75-0 \cdot 89$, but reducing to typically $0 \cdot 22-0 \cdot 40$ by the final load stage. Secondary compression due to the realignment and, in particular, compression of the solids (residue flocs) became increasingly dominant at higher applied stresses due to the significant reduction in the hydraulic conductivity. For each specimen pair, the secondary compression strain values were consistently greater for the thinner specimens (one-way drainage, Table 4) since the relative magnitude of the secondary compression component increases as the specimen thickness decreases.

Dissipation of excess pore-fluid pressure measured at the specimen base $\left(\boldsymbol{u}_{\mathrm{b}}\right)$ under one-way drainage conditions is plotted against the logarithm of elapsed time in Figure 3. Some small changes in ambient laboratory temperature over the
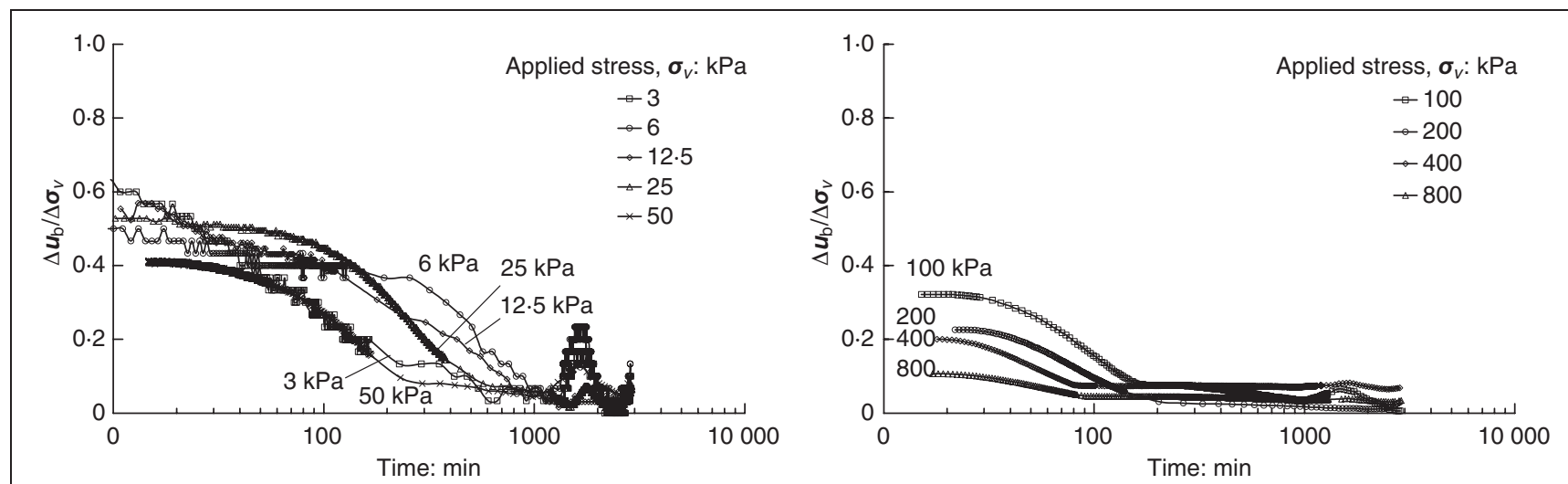

(a)
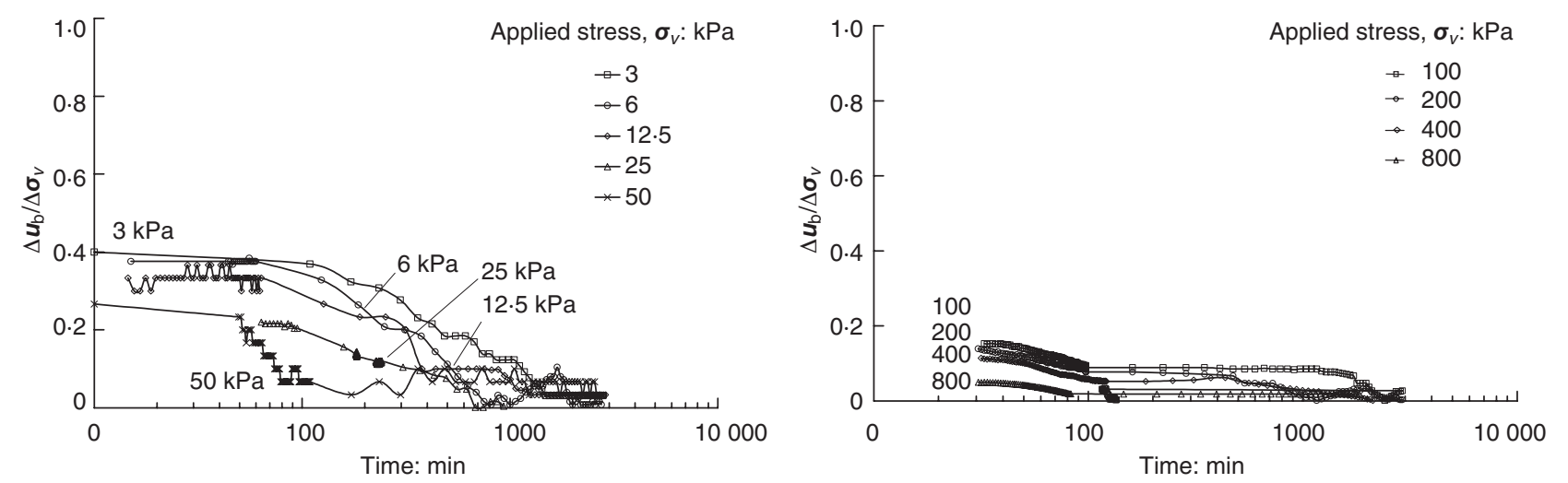

(b)
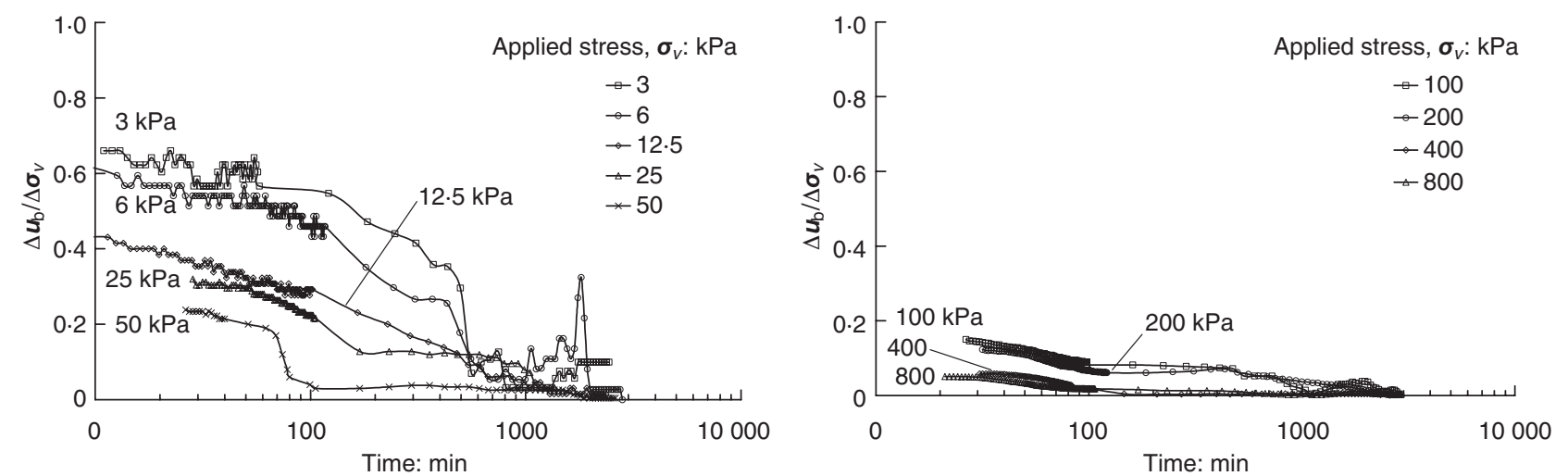

(c) 
course of the oedometer tests caused small cyclic variations in the transducer base readings, which are reflected in the data.

\subsection{Consolidometer}

Figure 4 shows the consolidometer data plotted as cumulative strain against logarithm of elapsed time. Again, the cumulative strain values of $26-36 \%$ achieved by the end of the final load stage at $30 \mathrm{kPa}$ were very large. Curve fitting of the characteristic S-shaped curves using the Casagrande method ${ }^{25}$ indicated that primary consolidation was substantially complete by the end of each load stage.

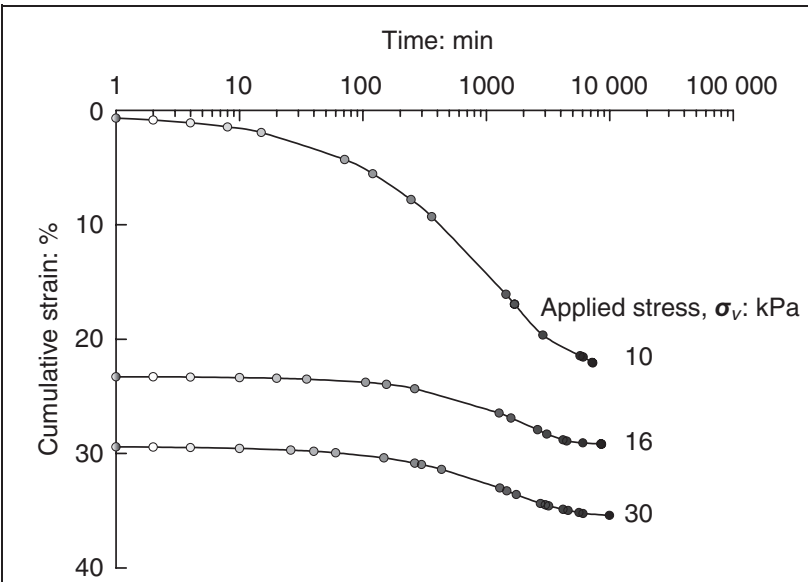

(a)

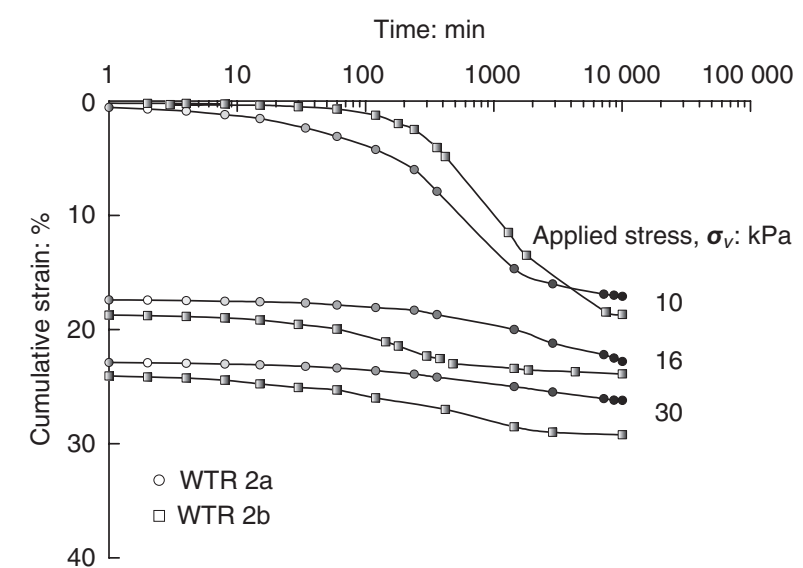

(b)

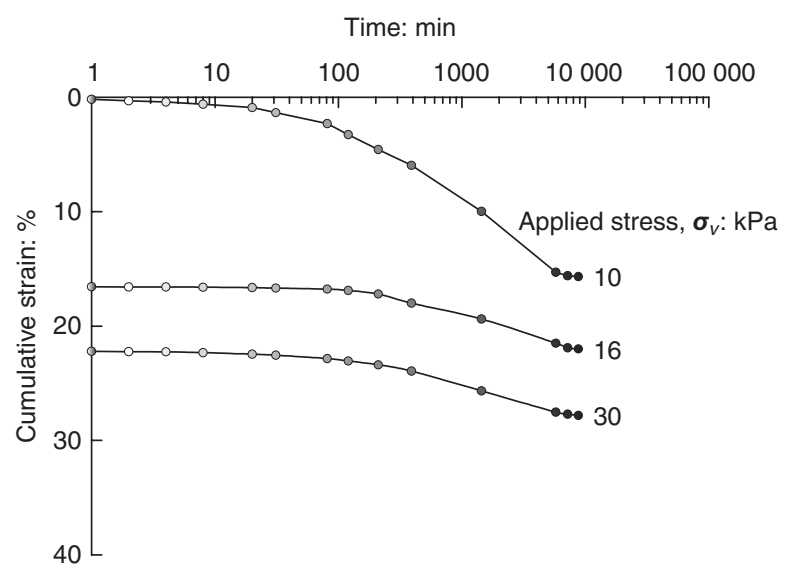

(c)

Figure 4. Consolidometer data: (a) WTR I; (b) WTR 2a and 2b: (c) WTR 3 (WTRs I, 2a and 3 are alum-coagulated residues; WTR $2 b$ is a non-chemically coagulated residue)

\subsection{Triaxial consolidation}

Figure 5 shows the triaxial consolidation data plotted as volumetric strain (i.e. change in volume expressed as a percentage of the initial specimen volume) against logarithm of elapsed time. Again, the final volumetric strains of 23-33\% experienced by the end of the $150 \mathrm{kPa}$ load stage were very large.

\subsection{Compressibility}

The stress-strain-time data from the one-dimensional load tests in the oedometer and consolidometer apparatus, and the singleincrement isotropic-consolidation tests in the triaxial apparatus are presented in the conventional form of void ratio against logarithm of effective stress $\left(e-\log \boldsymbol{\sigma}^{\prime}\right)$ plots in Figure 6 . The level of compression depends on a range of factors, in particular water content (void ratio), intrinsic permeability, specimen thickness, effective drainage length, applied stress and stage duration. For example, comparison of the strain responses in Figures 2 and 4 indicates that over the same stress range of 3$30 \mathrm{kPa}$, larger specimen strains were recorded in the consolidometer than in the oedometer tests (both under twoway drainage); this is mainly due to the longer duration of the consolidometer load-stages. Furthermore, WTR 1 had compressed to a higher degree by the end of the consolidometer and triaxial tests due to its higher initial void ratio and organic content (Figures 4 and 5).

The level of compression was quantified in terms of the primary compression index $C_{\mathrm{c}}$, defined as the gradient of the void ratio against logarithm of effective stress curves under onedimensional compression (Figure 6a). All of the WTRs were highly compressible, with values of $C_{\mathrm{c}}=3 \cdot 1,2 \cdot 1$ and $2 \cdot 6$ calculated from the oedometer data for WTRs 1, 2a and 3, respectively (for clay soils, $C_{\mathrm{c}}<1 \cdot 0$ and generally less than $0 \cdot 5$ ). As expected, slightly higher $C_{\mathrm{c}}$ values of $3 \cdot 9,2 \cdot 8,5 \cdot 5$ and $3 \cdot 1$ were calculated from the consolidometer data for WTRs 1, 2a, $2 \mathrm{~b}$ and 3 , respectively, due to the longer duration of the load stages. Primary compression ratio $C_{\mathrm{c}}^{*}$ (Equation 2) values of $0 \cdot 23,0 \cdot 19$ and 0.22 were calculated from the oedometer data for WTRs $1,2 \mathrm{a}$ and 3 , respectively.

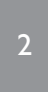

$$
C_{\mathrm{c}}^{*}=\frac{C_{\mathrm{c}}}{1+e_{0}}
$$

where $e_{0}$ is the initial void ratio.

\subsection{Consolidation}

Figure 7 shows the average degree of consolidation achieved under one-way drainage in the oedometer tests, calculated from the measured pore-fluid pressure response using the method presented by 0 'Kelly. ${ }^{17}$ The data generally indicated that 50\% primary consolidation had been achieved within the initial $10 \mathrm{~min}$ period and full dissipation of the excess pore-fluid pressure had been achieved by the end of each load stage.

The rate of primary consolidation settlement was quantified in terms of the coefficient of primary consolidation, with $c_{\mathrm{v}}$ and $c_{\mathrm{vi}}$ denoting one-dimensional and isotropic-consolidation conditions, respectively (Figure 8). Pairs of $c_{\mathrm{v}}$ values were calculated from strain against elapsed time data for each oedometer load stage using Casagrande and Taylor curve-fitting methods. ${ }^{25,26}$ A third set of $c_{\mathrm{v}}$ values was calculated on the basis of the average degree of consolidation data measured in 


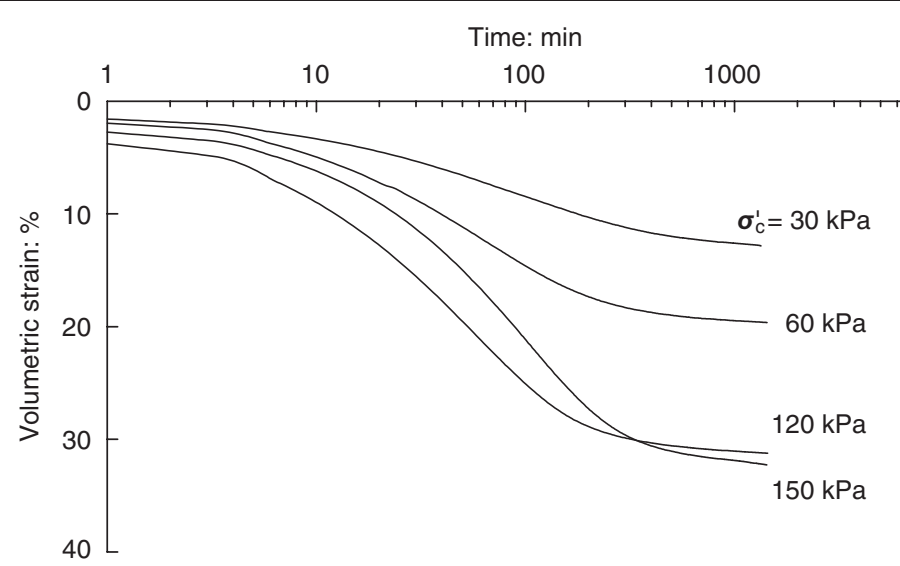

(a)
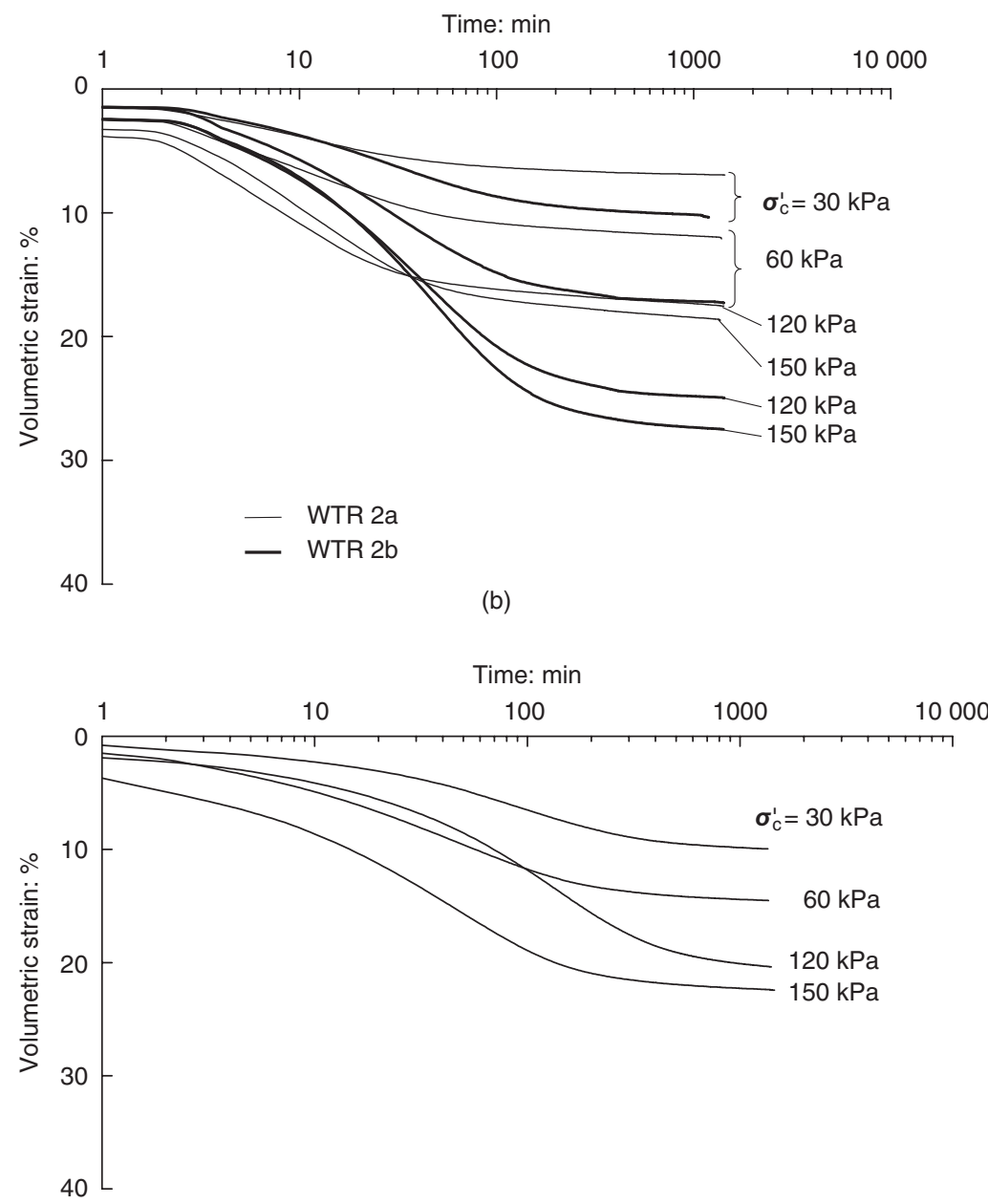

(c)

Figure 5. Triaxial consolidation: (a) WTR I; (b) WTR 2a and 2b; (c) WTR 3 (WTRs I, 2a and 3 are alum-coagulated residues; WTR 2b is a non-chemically coagulated residue; $\sigma_{c}^{\prime}$, effective cell-confining pressure)

the oedometer specimens under one-way drainage (Figure 7). The three sets of $c_{\mathrm{v}}$ values were in good agreement and the mean of the three values calculated for a particular load stage and WTR are shown in Figure 8(a). The $c_{\mathrm{vi}}$ values shown in Figure $8(\mathrm{~b})$ were calculated from the triaxial consolidation data using a standard curve-fitting method. ${ }^{25}$

In general, the coefficient of primary consolidation values for the three WTRs were similar, although low overall, tending to increase from typically $0 \cdot 1$ to $0 \cdot 8 \mathrm{~m}^{2} /$ year with increasing effective stress from $3-800 \mathrm{kPa}$.

\subsection{Hydraulic conductivity}

Hydraulic conductivity (coefficient of permeability $k$, Equation 3) was determined indirectly from the oedometer data

$3=m_{\mathrm{v}} \mathrm{c}_{\mathrm{v}} \gamma_{\mathrm{w}} \quad(\mathrm{m} / \mathrm{s})$ 


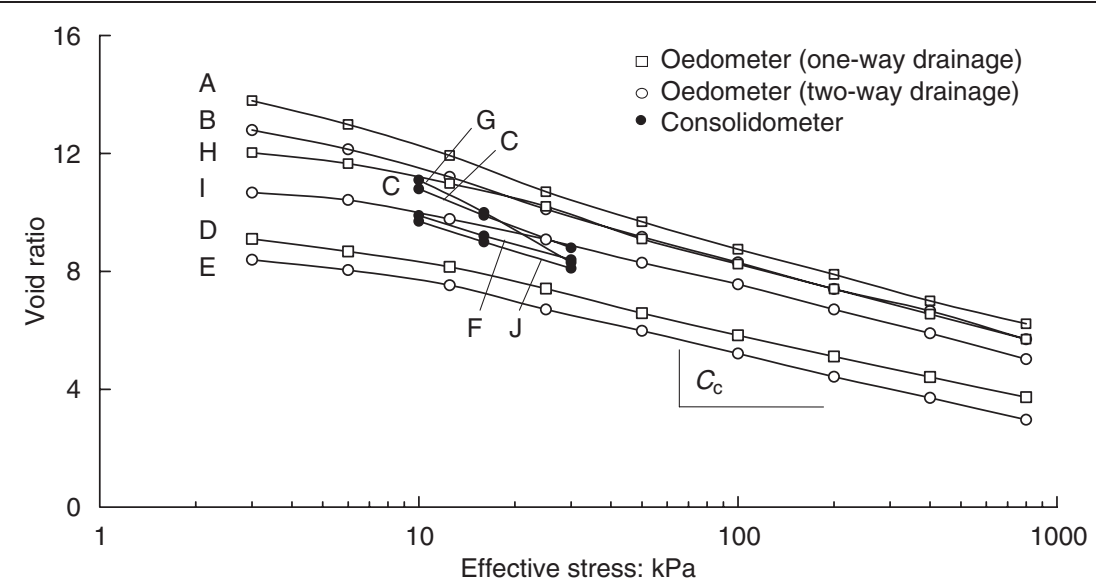

(a)

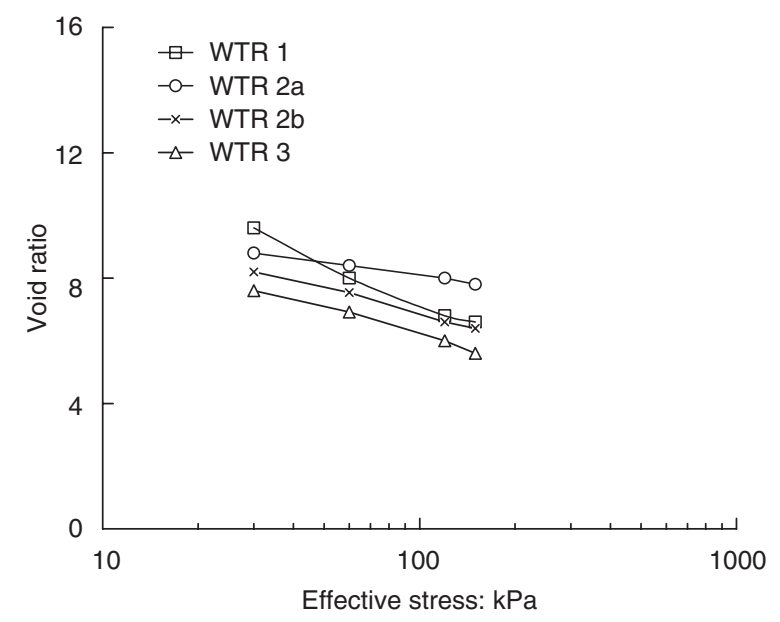

(b)

Figure 6. Void ratio plotted against logarithm of effective stress: (a) one-dimensional consolidation (A, B, C, WTR I; D, E, F, WTR 2a; G, WTR 2b; H, I, J, WTR 3; C, primary compression index); (b) isotropic consolidation

where $m_{\mathrm{v}}$ and $c_{\mathrm{v}}$ are the coefficients of volume change and primary consolidation, respectively, and $\gamma_{\mathrm{w}}$ is the pore-fluid density (assumed $0.98 \mathrm{t} / \mathrm{m}^{3}$ ).

The coefficient of permeability values calculated using the three sets of $c_{\mathrm{v}}$ values from the curve-fitting analysis were in good agreement and the means of the coefficient of permeability values corresponding to a particular stress level and WTR are plotted in Figure 9a. The three residues had very low coefficient of permeability values, which decreased significantly with increasing effective stress (reduction in water content and void ratio) from typically $2 \times 10^{-9}$ to $2 \times 10^{-11} \mathrm{~m} / \mathrm{s}$ over the effective stress range $3-800 \mathrm{kPa}$. This is consistent with the experience of mechanically dewatering a wet residue at a treatment plant, which is best achieved under the higher stresses applied by a recessed-plate filter press (final water contents of 235-400\% (Table 1)). Further reductions in water content can generally only be achieved by thermal treatment or by allowing the wet residue to naturally air dry in a drying bed or lagoon. In general, the coefficient of permeability was found to be inversely related to the effective stress on a log-log plot, according to Equation 4

$4 \mathrm{a} \quad \log k=-8 \cdot 8-0.47 \times \log \boldsymbol{\sigma}_{\mathrm{v}}(\mathrm{m} / \mathrm{s})($ WTR 1$)$ $\log k=-7 \cdot 2-0.66 \times \log \sigma_{\mathrm{v}} \quad(\mathrm{m} / \mathrm{s})($ WTR 2a)

$\log k=-7.6-0.54 \times \log \boldsymbol{\sigma}_{\mathrm{v}} \quad(\mathrm{m} / \mathrm{s})(\mathrm{WTR} 3)$

The very low coefficient of permeability values are due to the intricate microstructure of the constituent flocs, ${ }^{17}$ which tends to trap interstitial water, and the fact that the alum is mainly present in an amorphous form and is therefore strongly hydrated. ${ }^{13}$ Direct comparisons at the same levels of effective stress indicated that the coefficient of permeability values for WTRs 2a and 3 were broadly similar, and about one order of magnitude greater than that for WTR 1. It is postulated that this difference is in part due to the slightly higher organic content of WTR 1 . The coefficient of permeability data are also plotted as functions of void ratio in Figure $9 \mathrm{~b}$ and water content in Figure 9c, parameters that can be readily calculated in practice using phase relationships.

\subsection{Creep}

The rate of creep settlement (secondary compression) was quantified in terms of the coefficient of secondary compression $C_{\text {sec }}$, defined as the increase in strain per tenfold increase in elapsed time after the end of the primary consolidation phase, 


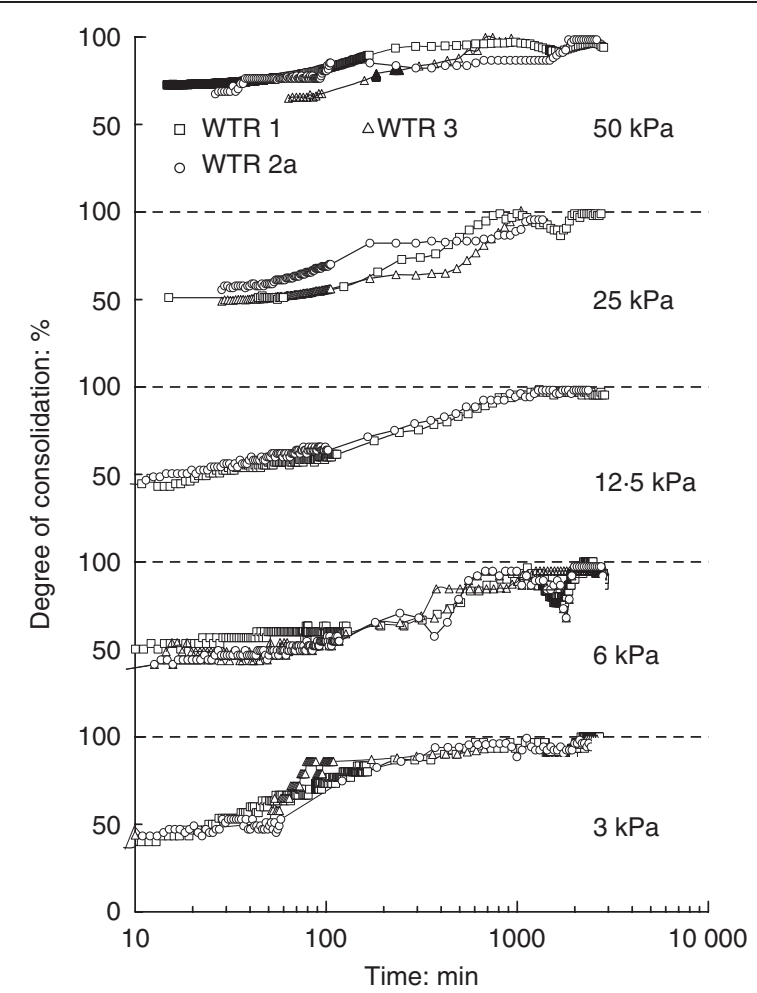

(a)

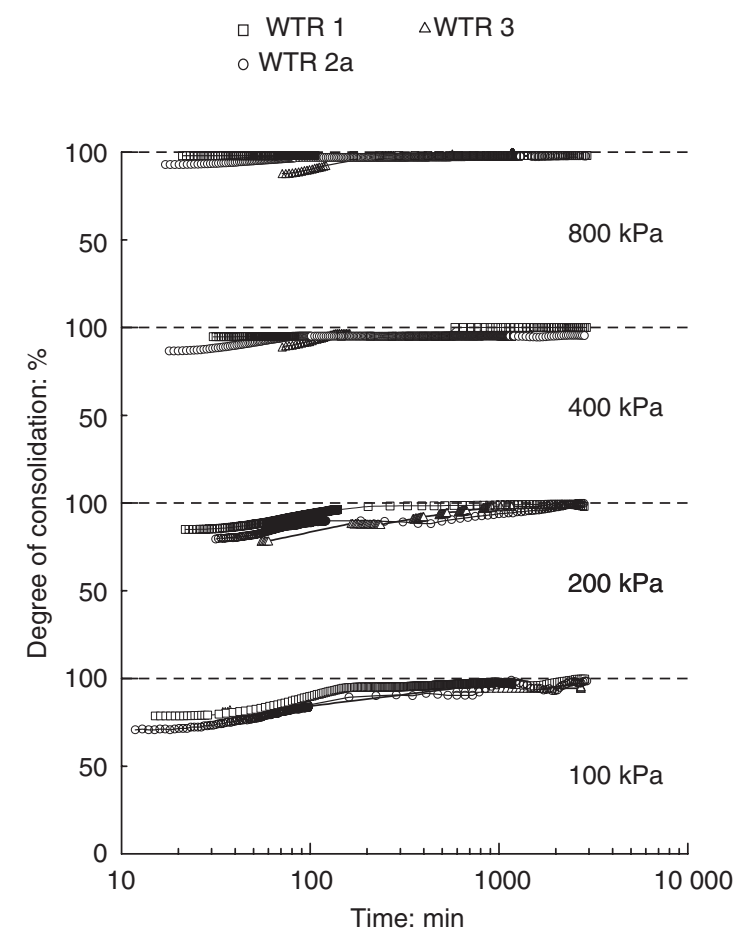

(b)

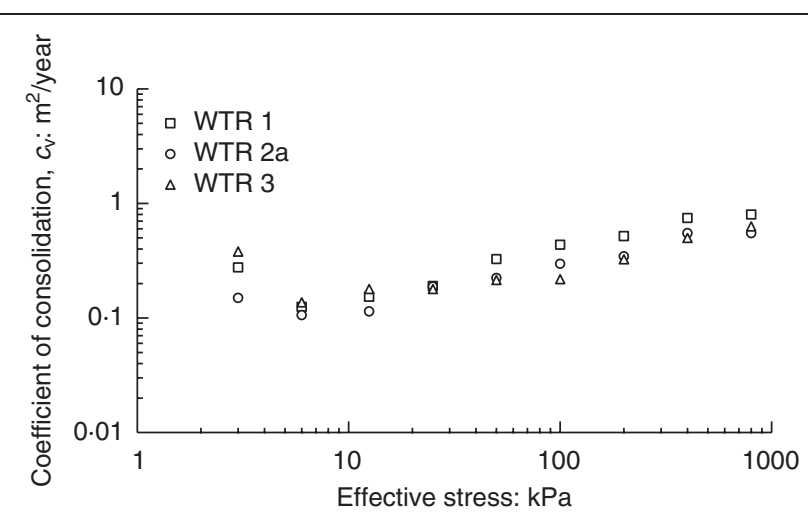

(a)

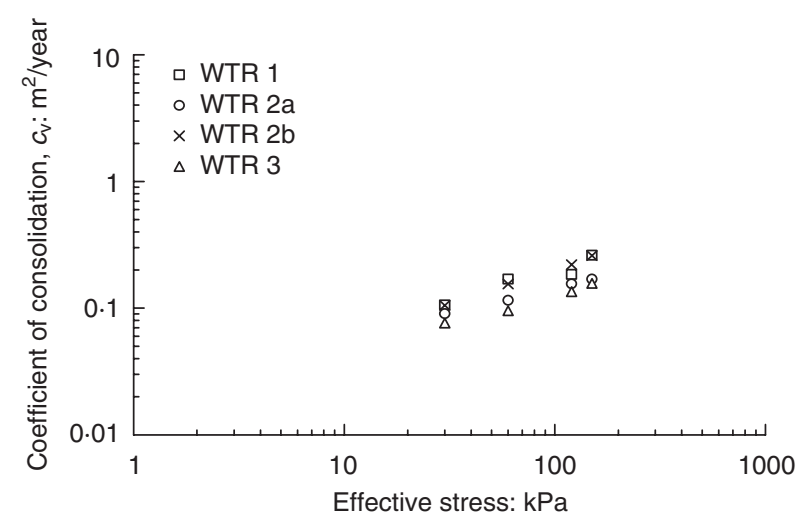

(b)

Figure 8. Coefficient of consolidation plotted against effective stress: (a) oedometer; (b) triaxial consolidation and under one-dimensional loading conditions. In general, the $C_{\text {sec }}$ values of between 0.005 and 0.010 were high and in good agreement, with a mean value of 0.006 over the effective stress range of 3-800 $\mathrm{kPa}$, which is typical of peaty and organic soils (Figure 10). The secondary compression index $\left(C_{\alpha \mathrm{e}}\right.$ (Equation 5)) ranged between $0 \cdot 15$ and $0 \cdot 18$, with a mean of $0 \cdot 16$ over the stress range. Values of $C_{\alpha \mathrm{e}} / C_{\mathrm{c}}$ (introduced by Mesri et al. ${ }^{27}$ ) of 0.03-0.05, with a mean value of 0.04 over the stress range, are shown in Figure 10 . The range of $C_{\mathrm{sec}}, C_{\alpha \mathrm{e}}$ and $C_{\alpha \mathrm{e}} / C_{\mathrm{c}}$ values are typical of high-plasticity organic clay.

\begin{tabular}{|l|l|}
\hline 5 & $C_{\alpha \mathrm{e}}=C_{\mathrm{sec}}\left(1+e_{0}\right)$ \\
\hline
\end{tabular}

\subsection{Effects of chemical additives and different water sources}

Alum coagulant and polyelectroyltes were added to the source waters entering the treatment plants to encourage coagulation of the suspended particles into larger flocs that settle out more readily under gravity. The chemical dosages added were broadly similar at the three plants (Table 2), although at the higher end of the ranges normally used in practice since the source waters were medium to high in turbidity. Although the test materials had been derived from three different catchments and sampled at different time periods, and allowing for natural variability in source waters, the alum WTRs generally had similar index, compression and consolidation properties (Table 3, Figures 6 and 8). Hence, the residues proved to be equally difficult to dewater at the treatment plants. This was mainly due to the fact that the residues had very high organic contents, which tended to dominate their engineering and drainage behaviour. Although necessary for efficient settlement processes at treatment plants, the chemical additives had the negative effect of reducing 


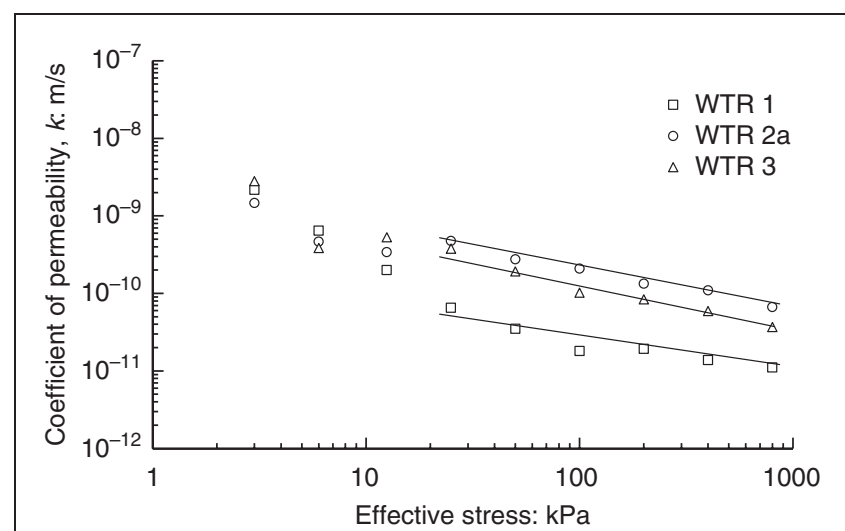

(a)

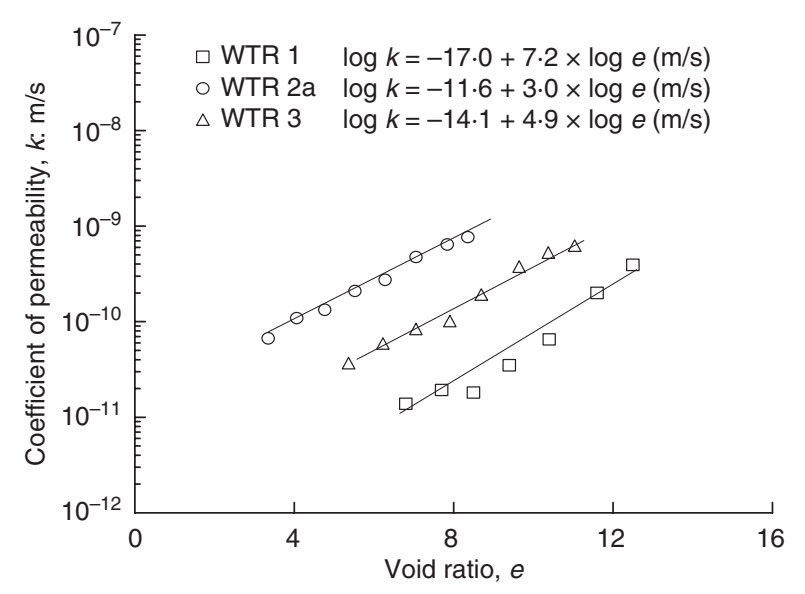

(b)

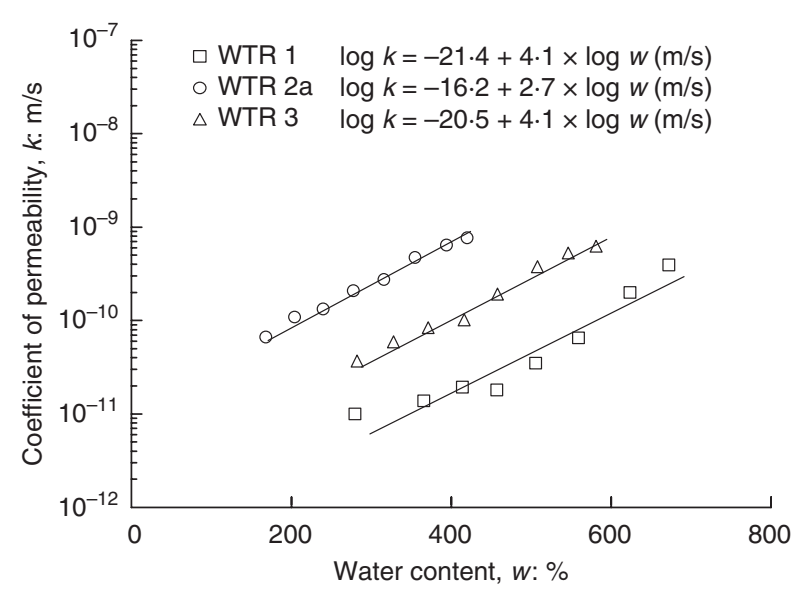

(c)

Figure 9. Coefficient of permeability plotted against (a) effective stress, (b) void ratio and (c) water content

dewaterability and hence the level and rate of consolidation of the residues. For example, WTR 2a was less compressible than the non-chemically coagulated WTR $2 \mathrm{~b}$ in consolidometer and triaxial consolidation tests (Figures 4 and 5), with primary compression index values of $2 \cdot 8$ and $5 \cdot 5$, respectively (Figure 6). In addition, the coefficient of primary consolidation, and hence the hydraulic conductivity, of WTR 2a was marginally lower than that measured for WTR $2 \mathrm{~b}$, with the difference increasing in value with increasing effective stress (Figure 8b). The hydraulic conductivity is reduced by the relatively large amount of pore water that is trapped and absorbed within the intricate matrix of colloidal particles, aluminium hydroxide precipitates and polyelectrolyte molecules. Turchiuli and Fargues ${ }^{28}$ also noted the difficulty of mechanically dewatering alum WTRs.

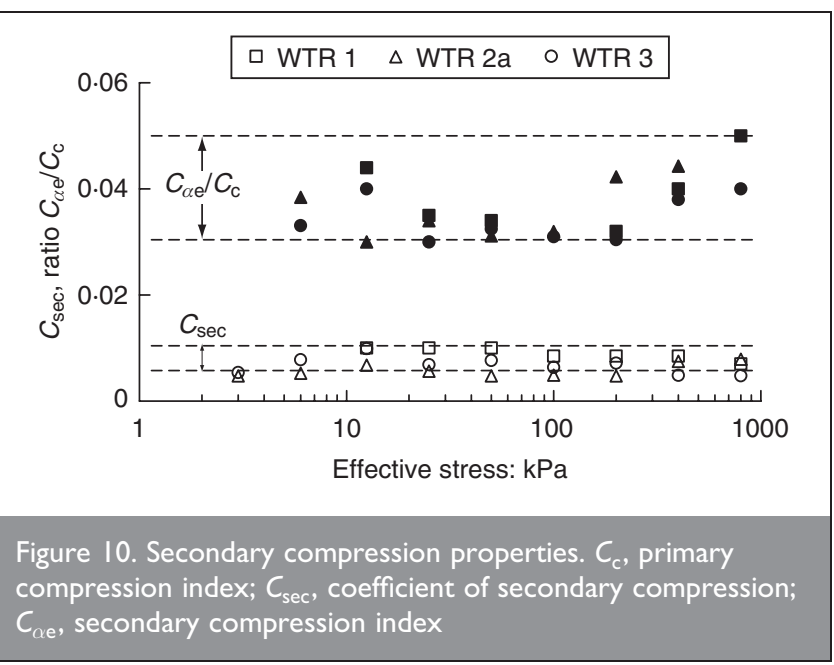

\section{APPLICATION OF TEST DATA}

\section{I. Mechanical dewatering}

Different levels of dewatering can be achieved at a treatment plant depending on the type of mechanical dewatering system used (Table 1). A higher level of dewatering produces a residue cake with a greater undrained shear strength, which is more efficiently handled by machine plant and lower transportation and landfill disposal costs due to the greater reduction in residue volume achieved at the treatment plant. The volume reduction (decrease in void ratio) achieved using a particular dewatering system can be estimated using Equation 6 and the $e-\log \boldsymbol{\sigma}_{\mathrm{v}}^{\prime}$ data presented in Figure $6 \mathrm{a}$.

\begin{tabular}{|l|l|}
\hline 6 & $\frac{\Delta V}{V_{0}}=\frac{\Delta e}{1+e_{0}}$ \\
\hline
\end{tabular}

where $\Delta V$ is the volume reduction, $V_{0}$ is the initial volume, $e_{0}$ is the initial void ratio and $\Delta e$ is the reduction in void ratio under the stress applied by the dewatering system.

\subsection{Settlement of lagoons and monofills}

The time-dependent settlement response comprises the sum of the primary consolidation and secondary compression phases ( $\Delta H_{\mathrm{c}}$ and $\Delta H_{\mathrm{sec}}$, respectively) and is readily calculated for onedimensional loading conditions using Equations 7 and 8.

Significant settlement of lagooned or landfilled residue can be expected to occur over a long period of time, due to the large primary compression index and coefficient of secondary compression values. The time period before substantial completion of the primary consolidation phase $\left(t_{1}\right)$ can be estimated using Equation 9.

\begin{tabular}{|l|c|}
\hline 7 & $\Delta H_{\mathrm{c}}=H_{0} \frac{C_{\mathrm{c}}}{1+e_{0}} \log \frac{\boldsymbol{\sigma}_{\mathrm{v} 0}^{\prime}+\Delta \boldsymbol{\sigma}_{\mathrm{v}}}{\boldsymbol{\sigma}_{\mathrm{v} 0}^{\prime}}$ \\
\hline 8 & $\Delta H_{\mathrm{sec}}=H_{0} C_{\mathrm{sec}} \log \frac{t_{1}}{t_{2}}$ \\
\hline 9 & $t_{1}=\frac{T_{\mathrm{v}} d^{2}}{c_{\mathrm{v}}}$ \\
\hline
\end{tabular}


where $d$ is the effective drainage length of the deposit (initially $H_{0}$ in thickness), $T_{\mathrm{v}}$ is a time factor related to the average degree of consolidation achieved, $t_{2}$ is the time period that extends into the secondary compression phase $\left(t_{2}>t_{1}\right), \boldsymbol{\sigma}_{\mathrm{v} 0}^{\prime}$ is the initial vertical effective stress and $\Delta \boldsymbol{\sigma}_{\mathrm{v}}$ is the increase in vertical effective stress (i.e. applied stress). The primary compression index $C_{\mathrm{c}}$ (Figure 6a), coefficient of primary consolidation $\mathrm{c}_{\mathrm{v}}$ (Figure 8a) and coefficient of secondary compression $C_{\mathrm{sec}}$ (Figure 10) values that are inputted into Equations 7-9 must be consistent with the in situ effective stress conditions.

\section{SUMMARY AND CONCLUSIONS}

The index, compression and consolidation properties of three alum WTRs derived from different catchments and dewatered using different methods have been presented. The study highlights the application of conventional geotechnical laboratory testing and analysis to a difficult, challenging and unconventional geomaterial.

The index, compression and consolidation properties were found to be largely independent of seasonal variations in the source waters and the catchment geology. The WTRs mainly comprised organic matter and micro-organisms (LOI typically between 40 and 60\%), as well as sand and silt particles, and the material is classified as high-plasticity organic clay. The WTRs had low specific gravity of solids values of 1.83-1.99 and hence low dry density values of $0 \cdot 14-0 \cdot 26 \mathrm{t} / \mathrm{m}^{3}$ over the mass water content range of $300-700 \%$. The wet residue was highly compressible with a primary compression index $C_{\mathrm{c}}$ of $2 \cdot 1-3 \cdot 1$.

Although necessary to encourage coagulation, thereby increasing the efficiency of settlement processes at the treatment plants, the addition of alum and polyelectrolytes to the source water had the negative effect of reducing the dewaterability of the residue at the treatment plant and hence the rate of consolidation and shear strength gain of the lagooned or landfilled material. The non-chemically coagulated residue was also found to be slightly more compressible, with $C_{\mathrm{c}} \approx 5 \cdot 5$.

Significant settlement of lagooned or landfilled residues will occur, but at a reduced rate and over a long period of time, as their consolidation rate was low (coefficient of primary consolidation of $0 \cdot 1-0 \cdot 8 \mathrm{~m}^{2} /$ year) and the creep rate was high (secondary compression index of 0.005 to $0 \cdot 010$ ). The very low hydraulic conductivity of the residues (coefficient of permeability of $10^{-9}$ to $10^{-11} \mathrm{~m} / \mathrm{s}$ ) over the effective stress range of $3-800 \mathrm{kPa}$ was due to the floc microstructure, the residues' high organic content and alum's exceptionally high affinity for water. During floc growth, free water becomes adsorbed and trapped within the intricate matrix of colloidal particles, aluminium hydroxide precipitates and polyelectrolyte molecules.

\section{ACKNOWLEDGEMENTS}

The authors acknowledge the work of Martin Carney, Mbakure Johnson, Emma Quinn, Brian Devaney, Stephen Conlon and Patrick Fogarty in performing some of the tests on the residues at the geotechnical laboratory of Trinity College Dublin. The authors would also like to thank Paul Johnston for his helpful comments during the preparation of this paper. Michael Quille would like to acknowledge funding received from the
Geotechnical Trust Fund of the Institution of Engineers of Ireland and a postgraduate research studentship award from Trinity College Dublin.

\section{REFERENCES}

1. Twort A. C., Ratnayaka D. D. and Brandt M. J. Water Supply, 5th edn. Edward Arnold, London, 2000.

2. Page D., O'Leary G., Boland A., Cleanaghan C. and CRowe M. The Quality of Drinking Water in Ireland: Report for the Year 2001. Environmental Protection Agency, Dublin, 2002.

3. EUROPEAn Union. Directive 2000/60/EC of the European Parliament and of the Council of 23 October 2000 establishing a framework for Community action in the field of water policy. Official Journal of the European Communities, L327, 1-72.

4. EUROPEAN Union. Directive 98/15/EC of the European Parliament and of the Council of 27 February 1998 concerning urban wastewater treatment. Official Journal of the European Communities, L67/29, 1-55.

5. Metcalf and EdDy Inc. Wastewater Engineering: Treatment and Reuse, 4th edn (revised by Tchobanoglous G., BuRToN F. L. and STENSEL H. D.). McGraw-Hill, New York, 2003.

6. Raghu D. and Hsien H.-N. Material properties of water treatment plant sludges. Civil Engineering for Practicing and Design Engineers, 1986, 5, No. 11/12, 927-941.

7. Сhiн Chao W., Chinpin H. and LeE D. J. Effects of polymer dosage on alum sludge dewatering characteristics and physical properties. Colloids and Surfaces A:

Physicochemical and Engineering Aspects, 1997, 122, No. 1-3, 89-96.

8. Geuzens P. and Dieltuens W. Mechanical strength determination of cohesive sludges. In A Belgian Research Project on Sludge Consistency (Colin F., Newman P. J. and Puolanne Y. J. (eds)). Elsevier, London, 1991, pp. 14-23.

9. Lim S., Jeon W., LeE J., LeE K. and Kim N. Engineering properties of water/wastewater-treatment sludge modified by hydrated lime, fly ash and loess. Water Research, 2002, 36, No. 17, 4177-4184.

10. NovaK J. T. and Calkins D. C. Sludge dewatering and its physical properties. Journal of the American Water Works Association, 1975, 67, No. 1, 42-45.

11. Roque A. J. and Carvalho M. Possibility of using the drinking water sludge as geotechnical material. Proceedings of the 5th International Congress on Environmental Geotechnics, Cardiff, 2006, 2, 1535-1542.

12. Wang M. C., Hull J. Q., Jao M., Dempsey B. A. and Cornwell D. A. Engineering behavior of water treatment sludge. ASCE Journal of Environmental Engineering, 1992, 118, No. 6, 848-864.

13. Wang M. C. and Tseng W. Permeability behavior of a water treatment sludge. ASCE Journal of Geotechnical Engineering, 1993, 119, No. 10, 1672-1677.

14. O'KelLy B. C. Geotechnical aspects of sewage sludge monofills. Proceedings of the Institution of Civil Engineers, Municipal Engineer, 2004, 154, No. 3, 193-197.

15. O'Kelly B. C. Geotechnical properties of municipal sewage sludge. Geotechnical and Geological Engineering, 2005, 24, No. 4, 833-850.

16. O'KelLy B. C. Consolidation properties of a dewatered municipal sewage sludge. Canadian Geotechnical Journal, 2005, 42, No. 5, 1350-1358. 
17. O'KelLy B. C. Effect of biodegradation on the consolidation properties of a dewatered municipal sewage sludge. Waste Management, 2008, 28, No. 8, 1395-1405.

18. BRITISH STANDARDS InSTITUTION. Methods of Test for Soils for Civil Engineering Purposes: Classification Tests. BSI, London, 1990, BS 1377: Part 2.

19. British Standards Institution. Methods of Test for Soils for Civil Engineering Purposes: Chemical and Electro-chemical Tests. BSI, London, 1990, BS 1377: Part 3.

20. GibBs H. J. and Holtz W. G. Engineering properties of expansive clays. Transactions of the American Society of Civil Engineers, 1956, 121, No. 1, 641-677.

21. Titshall L. W. and Hughes J. C. Characterisation of some South African water treatment residues and implications for land application. Water SA, 2005, 31, No. 3, 299-307.

22. TerzAghi K. Theoretical Soil Mechanics. Wiley, New York, 1943.

23. O'KelLy B. C. Development of a large consolidometerpermeameter apparatus for testing soft soils. Proceedings of the ASCE GeoCongress on the Challenge of Sustainability in the Geoenvironment, New Orleans, 2008, Vol. 5, pp. 60-67.

24. BRITISH StANDARdS InStITUTION. Methods of Test for Soils for Civil Engineering Purposes: Compressibility, Permeability and Durability Tests. BSI, London, 1990, BS1 377: Part 5.

25. Casagrande A. and Fadum R. E. Notes on Soil Testing for Engineering Purposes. Harvard University Graduate School of Engineering, 1940, Publication 8.

26. TAYLOR D. W. Research on Consolidation Clays. Massachusetts Institute of Technology, 1942, Report 82.

27. Mesri G., Shahien M. and Feng T. W. Compressibility parameters during primary consolidation. Proceedings of an International Symposium on Compression and Consolidation of Clayey Soils, Hiroshima, 1995, Vol. 2, pp. 1021-1037.

28. TuRchiuli C. and FARgues C. Influence of structural properties of alum and ferric flocs on sludge dewaterability. Chemical Engineering, 2004, 103, No. 1-3, 123-131.

\section{What do you think?}

To comment on this paper, please email up to 500 words to the editor at journals@ice.org.uk

Proceedings journals rely entirely on contributions sent in by civil engineers and related professionals, academics and students. Papers should be 2000-5000 words long, with adequate illustrations and references. Please visit www.thomastelford.com/journals for author guidelines and further details. 